\title{
Part of Speech Mastery of Thai Students of Xavier Learning Community, Thailand
}

\author{
Sumit Choemue ${ }^{1}$, Barli Bram ${ }^{2}$ \\ Xavier Learning Community Chiang Rai ${ }^{1}$, Thailand, Sanata Dharma University ${ }^{2}$, Indonesia \\ Correspondence: Barli Bram, Sanata Dharma University, Yogyakarta, Indonesia. email: barli@usd.ac.id \\ Received: September 03, $2020 \quad$ Revised: October 17, $2020 \quad$ Accepted: October 19, 2020 \\ DOI: $10.29408 /$ veles.v4i2.2540 URL: http://dx.doi.org/10.29408/veles.v4i2.2540
}

\begin{abstract}
This paper investigated the Thai students' mastery of parts of speech in English. It is urgent to conduct this study because it would explore the students' difficulties in identifying parts of speech when producing grammatical sentences and then assist them in tackling the language challenges. The data consisted of 30 written reflections produced by students belonging to two classes and were collected from all of the 30 students of batch 2018 pursuing their Bachelor of Arts degrees at Xavier Learning Community (XLC) in Chiang Rai, Thailand. This error analysis study examined the (mis)use of the four main parts of speech or syntactic categories, namely adjectives, adverbs, nouns and verbs in written reflections of XLC students. Results showed that in general the students still faced challenges in recognizing and using parts of speech grammatically in writing reflections. The highest number of mistakes involved adjectives, namely 32 times (46.37\%), and consecutively followed by nouns, 18 (26.08\%), verbs, 15 (21.73\%) and adverbs, 4 $(5.79 \%)$.
\end{abstract}

Keywords: Grammatical sentence, part of speech, writing, Xavier Learning Community

\section{Introduction}

Among the four English skills, writing is widely considered as the most difficult and challenging skill in English to be acquired by the second language (L2) and English as a foreign language (EFL) learners (Phuket \& Othman, 2015). Bram (2012) states that writing is complicated for the reason that it is a "process and product" which involves a lot of learners' energy. Therefore, in composing grammatical and semantic writing, learners need basic language skills including profound knowledge of grammar structure, and sufficient vocabulary (Hinnon, 2014; see also Baron, 2020 \& Murtisari, 2020). Watcharapunyawong and Usaha (2013) claim that some negative effects holding back learners' writing proficiency can be found within those who possess inadequate linguistic knowledge and or imperfect language capability. One possible solution is that teachers need to be able to analyze errors in writing made by the learners to assist them to 
fruitfully achieve writing skills (Hasyim, 2002). Nevertheless, despite many difficulties faced by learners in acquiring writing expertise, being a proficient writer becomes a major goal for many learners. To emphasize its importance, writing is not only viewed as a tool used for communication in this era (Long, Ming, \& Chen, 2013), but it plays a significant role in "international business, administrative or academic communities" (Sattayatham \& Ratanapinyowong, 2008). Therefore, mastering writing skills is advantageous for learners in both educational and professional aspects.

In Thailand, English is one of the compulsory subjects for all Thai students from primary to higher education to take and pass (Kongkerd, n.d.). Nonetheless, English teaching and learning tends to underpin students to pass the international examination to be accepted in well-known universities. Yet, the important learning objectives are, to some extent, neglected. Therefore, this kind of teaching and learning method prominently affects students to have unsatisfied learning outcomes. In brief, students cannot utilize their knowledge for their lifelong learning. In writing, for instance, Thai students generally start learning how to write basic sentences, compound sentences, and complex sentences since they are in high school (Dueraman, 2015). Besides, the importance of writing is recognized by many universities since students are asked to register provided writing courses, especially English major students. However, students still struggle for constructing grammatical sentences and yet, their writing capabilities still need to be developed (Kaweera, 2013).

Concerning writing difficulties faced by Thai students, many research studies have been conducted to examine and support students to strengthen their writing skills. Bennui (2016), for example, explores how the mother tongue or the first language interference influences Thai university students' writing (see also Hinnon, 2014; Phuket \& Othman, 2015 \& Watcharapunyawong \& Usaha, 2013). Bennui (2016) demonstrates that L1 interference is likely to have negative effects on their paragraph writing, especially when they use vocabulary, construct sentences, and select language style. These problems can be solved if the teachers realize and they implement appropriate methods to enrich students' writing skills (Bennui, 2016). Furthermore, Hemchua and Schmitt (2006) investigate the lexical errors committed by Thai students. The results indicate that most of the students are struggling with three aspects, namely 'neighboring synonyms', prepositions, and suffixes respectively. Surprisingly, it is also found that L1 is not the major impact of lexical errors in Thai students' writings. Additionally, for English is not used as the core communicative language in other subjects and Thai students merely speak English in the English classroom, some researchers believe that it becomes a weakness of Thai students to learn L2 language effectively (Sattayatham \& Ratanapinyowong, 2008). Besides, it undeniably undermines their writing skills.

Established in 2015, Xavier Learning Community (XLC), however, attempts to create a supportive English language learning environment in the community by encouraging students to use English as the main communicative language both inside and outside the classroom. Besides, XLC students are strongly encouraged to communicate with English native speakers and as well as with foreigners from different countries during their four-year study program. As a result, listening and speaking skills are likely to be acquired easier than the other two skills by XLC 
students. The researchers found that writing was the most challenging skill for most XLC students. However, it is essential to be acknowledged that, more than $90 \%$ of them are students from various ethnic minorities, such as Karen, Akha, Hmong, Lahu, and Lanna, where English is considered as their third language which they have studied for at least six years. Although they have learned English for many years, they are likely to have difficulties in producing grammatically correct sentences. More prominently, the researchers discovered that the students encountered difficulties in recognizing parts of speech both in spoken and written English.

Nevertheless, the challenges are highlighted as XLC provides several writing courses to assist the students in developing their writing skills and prepare them to be ready for their future careers in a competitive world. As a Jesuit institution, XLC considers that reflections play a significant role in shaping XLC students to become whole persons. Writing reflections, once a month or at least at the end of the semester, supports students to become critical thinkers and reflective people. However, withheld by many impacts, XLC students still struggle in their grammatical writing. Consequently, this error analysis study, focusing on syntactic aspects, was conducted to investigate Thai students' mastery of parts of speech in English. It aimed to examine the (mis)use of the four main parts of speech or syntactic categories, namely adjectives, adverbs, nouns and verbs in written reflections of XLC students. It is expected that this study will shed some new light for the teachers to find other effective strategies to support XLC students to have better understandings of the parts of speech and also to help them improve their writing skills.

In the context of this paper, it is relevant to discuss error analysis (EA), which was developed and introduced in the 1960s as an alternative to the contrastive analysis (CA) (Khansir, 2012). Dulay and Burt (1972) state that the error analysis is a study of the types and the causes of language errors committed by the second and foreign language learners when they learn a targeted language. Another definition of error analysis proposed by James (1998) and Crystal (1999 cited in Sermsook, Liamnimitr, \& Pochakorn, 2017) is the ability to compare what the learners have learned with what they lack in the second and foreign language acquisition. Furthermore, they emphasize the importance of explaining errors for learners to avoid and reduce them.

As error analysis (EA) was postulated a long time ago, it seems to be an obsolete method to be used (Selinker, 1992; Abushihab, 2014). However, it is undeniable that error analysis still plays an imperative role in English language learning and teaching (Zheng \& Park, 2013). It means that EA has received a lot of interest from teachers to implement this method to figure out the writing problems encountered by learners, analyze the errors influenced by various types of barriers, and later on, teachers apply effective strategies to enhance their students' writing (An, 2005).

There are two purposes in conducting error analysis described by Corder (1983), namely the theoretical aim and practical aim (cited in Azevedo, 1983; see also Chen, 2002). First, Corder (1983) believes that EA can help teachers find what and how learners learn a language. The second reason is to support teachers to strengthen learners to attain the targeted language successfully by making use of their prior knowledge or from what they have already learned before; there exist five steps of applying EA, namely (a) collecting the errors, (b) identifying the errors, (c) describing the errors, (d) explaining the errors, and (e) evaluating the errors. 
In the past decades, scholars had discussed the sources or causes of errors. Richards (1974) mentioned two main sources of errors: interlingual errors and intralingual errors. The first one is the mother-tongue interference or the first language (L1), namely when learners wrongly use the rules from L1 in producing sentences of the target language. The second one occurs during the process of achieving the target language; the causes of this error can be seen as a false analogy and incomplete rule, for example.

Dulay, Burt, and Krashen (1982) differentiated the sources of errors into six types: (1) learners tend to ignore grammatical morphemes, (2) use twice semantic features, (3) misuse irregular rules, (4) use the wrong word forms, (5) use two or more forms, and (6) misordering of item. Afterwards, Norrish (1987) classified the causes of errors into three types, namely carelessness, first language (L1) interference, and translation. Moreover, Odin (1989 cited in Hinnon, 2014) categorized four levels of errors: (a) grammar level which can be subcategorized into three parts namely word order, relative clause, and negation, (b) phonetic level, (c) lexical level, and (d) discourse level which can be separated into two aspects: politeness and coherence when using transitional words.

From the reviews above, it can be concluded that there are two major sources used to explain errors made by learners, namely interlingual interference and intralingual interference. Furthermore, it is apparent that error analysis is crucial since it is not only beneficial for the learners in acquiring a target language, but it also reinforces the teacher to be able to detect the problems and the challenges of the learners. Later, the teachers can carefully select the appropriate strategies and develop learning materials to fit the needs of the learners in increasing their writing skills.

Next, the relevance of parts of speech in this study will be elaborated. According to Schachter and Shopen (2007), the term syntactic categories or parts of speech (PoS) is "the traditional term used to refer to the major classes of words or lexemes that are distinguished in a language" (see also Azar, 2002; \& Bauer, 2007). Parts-of-speech differences are made in all languages. Therefore, it is beneficial to know "what generalizations can be made about parts-of-speech systems". Hengeveld (1992) improves his PoS theory and suggested the classification of parts-of-speech systems and he defined the classification as "the syntactic slot or slots that their members can reside in a statement". Moreover, he later differentiates four possible syntactic slots. Based on the study of Hengeveld, Rijkhoff, and Siewierska (2004), the four syntactic slots are head and modifier of a referential phrase and head and modifier of a predicate phrase. Heads are compulsory slots and modifiers are elective slots.

In this paper, the researchers investigated the four main parts of speech or syntactic categories, namely adjectives, adverbs, nouns and verbs which are considered as open parts of speech. Robins (1964, as cited in Schachter \& Shopen, 2007) defines open classes like those "whose membership is in principle unlimited, varying from time to time and between one speaker and another". Moreover, he also described closed classes as those that "contain a fixed and usually small number of member words, which are the same for all the speakers of the language, or the dialect" (Robins, 1964). Therefore, the open parts-of-speech classes are the classes of nouns, verbs, adjectives, and adverbs whereas closed classes are classes such as pronouns and conjunctions. 


\section{Method}

\subsection{Participants}

The participants of this study were 33 third-year English major students in Xavier Learning Community (XLC). There were 20 female students, $60.60 \%$, and 13 male students, $39.39 \%$ as shown in Table 1. As the researchers mentioned previously, more than $90 \%$ of XLC students were from different ethnic minorities in Thailand. Karen was the largest group in this study, totalling 69.69\%, Akha (18.18\%), Lahu (6.06\%) and Lanna (6.06\%) as shown in Table 2. Aged 20 to 24, the participants had learned English at least for six years. However, it is reasonable enough to say that they scarcely had experiences in English writing since it was not emphasized in their previous schools. Additionally, they had different levels of English skills. Therefore, they were systematically divided into two classes based on their entrance exam scores, namely Alpha class and Beta class since the beginning of the first semester. Beta students were considered as having a higher level of English skills including listening, speaking, reading, and writing than Alpha students.

Table 1. Participants categorized by gender

\begin{tabular}{lll}
\hline Gender & Member & Percentage \\
\hline Male & 13 & 39.39 \\
Female & 20 & 60.60 \\
\hline Total & 33 & 100 \\
\hline
\end{tabular}

Table 2. Participants categorized by ethnic minority

\begin{tabular}{lll}
\hline Ethnic Minority & Member & Percentage \\
\hline Akha & 6 & 18.18 \\
Lahu & 2 & 6.06 \\
Lanna & 2 & 6.06 \\
Karen & 23 & 69.69 \\
\hline Total & 33 & 100 \\
\hline
\end{tabular}

\subsection{Data Collection}

Data, consisting of written reflections, were collected from 30 Alpha and Beta students. First, they all were required to participate in the "Leadership course". This course was organized by two Jesuit priests and one Indonesian English teacher who have been teaching in Thailand for more than 10 years. This course was designed to prepare XLC students to become good leaders who are unselfish and who care about other people in the future.

Second, they were assigned to spontaneously write a reflection on what they have learned after participating in the program through reflecting themselves on the "SWOT", namely their strengths, weaknesses, opportunities, and threats. The 30 students completed their writing and submitted it to the researchers via e-mail. Each written reflection consisted of at least 100 words. 


\subsection{Data Analysis}

Three steps were taken. First, 30 pieces of written reflections of XLC students were analyzed by the researchers sentence by sentence to examine the (mis)use of the four main parts of speech or syntactic categories, namely adjectives, adverbs, nouns, and verbs. Second, all errors found in the writings were categorized according to the types of errors. Finally, the descriptive statistics used in this study were the frequency and percentage.

\section{Results and Discussion}

Based on the analysis, a total of 69 grammatical errors of the four main parts of speech or syntactic categories were identified. The results in Table 3 revealed that the highest frequency of grammatical errors made by XLC students was 'adjective', with 32 errors of the total (46.37\%). The second frequency was 'noun', 18 errors (26.08\%). The third was 'verb', 15 errors $(21.73 \%)$ and the last frequency was 'adverb', with 4 errors (5.79\%).

Table 3. Grammatical errors

\begin{tabular}{lll}
\hline Types of Errors & Frequency & Percentage \\
\hline Noun & 18 & 26.08 \\
Verb & 15 & 21.73 \\
Adjective & 32 & 46.37 \\
Adverb & 4 & 5.79 \\
\hline Total & 69 & 100 \\
\hline
\end{tabular}

Considering the results presented in Table 3 above, firstly, 'adjective' was the highest frequency of grammatical errors committed by XLC students among the four main parts of speech or syntactical categories. According to the results, they tended to misplace adjectives with nouns and verbs. The researchers found many interesting adjectives, such as responsible, self-confident, bored, boring, important, and challenging were used as a noun in the sentences by many students as in the following examples:

*It is the main important <importance> to lead people.

*We all have to face with challenging <challenge> and difficulty.

*They must use reasonable <reason> to solve the problems.

*... such as social media, laziness, boring <boredom>, and despondency.

*I have more responsible <responsibility> and reason to do something.

As most students were taught that the word ending -ing in English was considered as 'gerund' or 'noun', it can be explained from the examples above that XLC students used the words challenging and boring as nouns without being aware that these two words normally function as adjectives. Also, there were some adjectives used as verbs in the sentences. For example, in the sentence *I will not afraid <fear> to do a good thing. However, in this sentence, it can also be considered that students omitted the verb 'be', *I will not $\langle$ be $>$ afraid to do a good thing. 
Secondly, a noun was the second frequent error made by XLC students. Similar to an adjective, many nouns were misused as verbs or adjectives. To make it clear, it can be seen from the following examples.

*I learned how to servant others. (I learned how to serve others.)

*I will success. (I will succeed.)

The examples above demonstrated that the words servant and success were used incorrectly as verbs, instead of using serve and succeed. Furthermore, some nouns were used as adjectives in several sentences. For instance, the sentences were *I have to be more maturity $\langle$ mature $>$ and $* I$ must be a quality <qualitative> and quantity <quantitative> person. These errors may be affected by their inadequate vocabularies or misunderstandings of the functions of certain words.

Thirdly, there were 15 errors found in a verb. Most of the errors in these categories were also misused by XLC students. The sentences, for example, 'in my believe <belief>' and *they gave me encourage <courage> were used incorrectly. Instead of using belief and encouragement or they encouraged me, they misused those verbs as nouns. The researchers, additionally, found one significantly conspicuous error related to the verb made by the students. They tended to incorrectly use the verb form when trying to write in different tenses, especially with 'present perfect tense'. For example, the sentence *I have learn <learned> and *I have reflect<reflected>, the students should have been aware that in the contexts, 'have' must be followed by the past participle (verb $3)$.

Fourthly, as shown in Table 3, the syntactic category adverb was the lowest frequency of grammatical errors made by XLC students in their written reflections. Only 4 errors were found in all 30 pieces of writing and all of them were misused as an adjective. That is to say, the students sometimes incorrectly used some -ly words as an adjective as shown in the following:

*My works are perfectly. (My works are perfect.)

*I am a quite person. (I am a quiet person.)

Based on the data analysis, the researchers found two possible causes of the above errors made by XLC students regarding the four main parts of speech. In line with the results from Sermsook, Liamnimitr and Pochakorn (2017), the first cause was the students' limited knowledge of English grammar. The researchers found that XLC students still struggled when they attempted to include various tenses in their written reflections, such as the present simple, past simple, present continuous, and more importantly present perfect tense. Improving students' knowledge of English grammar is, therefore, an essential step to take. Besides, raising students' aware ness before they write can reduce the errors and help them to produce better and grammatical written reflections. As English vocabulary items are enormous and grow rapidly, the low mastery of vocabulary items was the second cause of errors. From the researchers' point of view, teaching the students basic knowledge of suffixes, such as -ion, -ive, -able, -ty, and -ly would be a good strategy to assist learners to increase their vocabulary items. This method is supported by the study of Pittman (2003), who states that students can build their vocabulary when they can recognize unfamiliar words by learning prefixes, roots, and suffixes. 


\section{Conclusion}

This study aimed to examine the (mis)use of the four main parts of speech or syntactic categories, namely adjectives, adverbs, nouns and verbs in written reflections of Xavier Learning Community (XLC) students. In general, the students still faced challenges in recognizing and using parts of speech grammatically in writing reflections. Based on the results, it can be concluded that adjective is the highest error committed by XLC students, with 32 out of 69 errors. To improve their students' writing skills, teachers can assist students in strengthening their knowledge of English grammar and in enriching their vocabulary items.

It is important to acknowledge that this study has some limitations. First, the results from this study cannot be used to generalize in the whole context of Thai students since the researchers conducted this study in one particular institution and all participants were from this institution, namely XLC in Chiang Rai, Thailand. Consequently, generalization should be done carefully. Second, the researchers only focused on the four main parts of speech and many other types of errors were found in their writings, such as punctuation, subject-verb agreement, and spelling. It is, therefore, recommended that future researchers should also investigate these errors to fully support students to sharpen their writing skills.

\section{References}

Abushihab, I. (2014). An analysis of grammatical errors in writing made by Turkish learners of English as a foreign language. International Journal of Linguistics, 6(4), 213-223. https://doi.org/10.5296/ijl.v6i4.6190

An, V. E. Ğ. (2005). Contribution of error analysis to foreign language teaching. Mersin Üniversitesi Ĕ̈itim Fakültesi Dergisi, 1(2), 261-270.

Azar, B. S. (2002). Understanding and using English grammar. (3 ${ }^{\text {rd }}$ ed.). New York: Pearson Education.

Azevedo, M. M. (1983). Error analysis and interlanguage (by S. Pit Corder: Book review). The Modern Language Journal, 67(1), 85-86. https://doi.org/10.2307/326720

Baron, R. (2020). Implementing of academic text in advanced grammar learning. VELES Voices of English Language Education Society, 4(1), 53-61.

Bennui, P. (2016). Malaysian journal of ELT research. Malaysian Journal of ELT Research, 4, $72-102$.

Bram, B. (2012). Learners' language challenges in writing English. Celt: A Journal of Culture, English Language Teaching \& Literature, 12(1), 1-15.

Chen, Y. M. (2002). The problems of university EFL writing in Taiwan. The Korea TESOL Journal, 5(1), 59-79.

Corder, S. P. (1981). Error analysis and interlanguage. Oxford: Oxford University Press.

Dulay, H. C., \& Burt, M. K. (1972). GOOFING: An indicator of children's second language learning strategies 1. Language learning, 22(2), 235-252.

Dulay, H., Burt M. \& Krashern, S. (1982). Language two. New York: Oxford University. 
Dueraman, B. (2015). The crucial point in time where Thai students are introduced to English language writing. English Language Teaching, 8(9), 96-103.

Gass, S. M., \& Selinker, L. (Eds.). (1992). Language transfer in language learning: Revised edition (Vol. 5). John Benjamins Publishing.

Hasyim, S. (2002). Error Analysis in the Teaching of English. 4(1), 42-50.

Hemchua, S., \& Schmitt, N. (2006). An analysis of lexical errors in the English compositions of Thai learners. Prospect : An Australian Journal of TESOL, 21(3), 3-25.

Hengeveld, K. (1992). Parts of speech. Layered Structure and Reference in a Functional Perspective: Papers from the Functional Grammar Conference, Copenhagen, pp. 29-55.

Hengeveld, K., Rijkhoff, J., \& Siewierska, A. (2004). Parts-of-speech systems and word order. Journal of Linguistics, 40(3), 527-570.

Hinnon, A. (2014). Common errors in English writing and suggested solutions of Thai university students. Humanities and Social Sciences, 31(2), 165-180.

Kaweera, C. (2013). Writing error: A review of interlingual and intralingual interference in EFL context. English Language Teaching, 6(7), 9-18. https://doi.org/10.5539/elt.v6n7p9

Khansir, A. A. (2012). Error Analysis and Second Language Acquisition. 2(5), 1027-1032. https://doi.org/10.4304/tpls.2.5.1027-1032

Kongkerd, W. (n.d.). Teaching English in the Era of English Used as a lingua franca in thailand. $3-12$.

Long, C., Ming, Z., \& Chen, L. (2013). The study of student motivation on English learning in Junior middle school -- A case study of No.5 middle school in Gejiu. English Language Teaching, 6(9), 136-145. https://doi.org/10.5539/elt.v6n9p136

Murtisari, E. (2020). Enhancing isolated grammar teaching through translation: Sentence level and beyond. LLT Journal: A Journal on Language and Language Teaching, 23(1), 157-167. doi: http://doi.org/10.24071/llt.2020.230112

Norrish, J. (1987). Language learning and their errors. London: Macmillan Publisher Ltd.

Parts-of-Speech Systems and Word Order Author(s): Kees Hengeveld, Jan Rijkhoff and Anna Siewierska Published by Cambridge University Press Stable URL: https://www.jstor.org/stable/4176901 University of Amsterdam. (2019). 40(3), 527-570.

Phuket, P. N. R., \& Othman, N. (2015). Understanding EFL students' errors in writing. Journal of Education and Practice, 6(32), 99-106.

Pittman, W. (2003). Building vocabulary through prefixes, roots and suffixes. The Internet TESL Journal, 9(7), 1-2.

Richards, J. C. (1974). Error analysis. London: Longman.

Sattayatham, A., \& Ratanapinyowong, P. (2008). Analysis of errors in paragraph writing in English by first-year Medical students from the four Medical schools at Mahidol University. Silpakorn University International Journal, 88, 17-38.

Schachter, P., \& Shopen, T. (2007). Parts-of-speech systems. Language Typology and Syntactic Description Second Edition: Volume 1: Clause Structure, I, 1-60. https://doi.org/10.1017/CBO9780511619427.001 
Sermsook, K., Liamnimitr, J., \& Pochakorn, R. (2017). An analysis of errors in written English Sentences: A case study of Thai EFL students. English Language Teaching, 10(3), 101-110. https://doi.org/10.5539/elt.v10n3p101

Watcharapunyawong, S., \& Usaha, S. (2013). Thai EFL students 'writing errors in different text types: The interference of the first language. 6(1), 67-78. https://doi.org/10.5539/elt.v6n1p67

Zheng, C., \& Park, T. J. (2013). An analysis of errors in English writing made by Chinese and Korean university students. Theory and Practice in Language Studies, 3(8), 1342-1351. 